\title{
Coral communities of Hong Kong: long-lived corals in a marginal reef environment
}

\author{
Nathalie F. Goodkin ${ }^{1,2, *}$, Adam D. Switzer ${ }^{3}$, Denise McCorry ${ }^{4}$, Lyndon DeVantier ${ }^{5}$, \\ James D. True ${ }^{2}$, Konrad A. Hughen ${ }^{6}$, N. Angeline ${ }^{1}$, Teng Teng Yang ${ }^{1}$ \\ ${ }^{1}$ Department of Earth Sciences, University of Hong Kong, Pokfulam Road, Hong Kong SAR \\ ${ }^{2}$ Swire Institute of Marine Science, University of Hong Kong, Cape D'Aguilar Road, Hong Kong SAR \\ ${ }^{3}$ Earth Observatory of Singapore, Nanyang Technological University, 50 Nanyang Avenue, Block N2-01a-04, \\ Singapore 639798 \\ ${ }^{4}$ Marine Team, Environmental Resources Management Australia, State One House, 6th Floor, 172 St. Georges Terrace, \\ Perth, Western Australia 6000, Australia \\ ${ }^{5} 20$ Val Crescent, Noosaville, Queensland 4566, Australia \\ ${ }^{6}$ Department of Marine Chemistry and Geochemistry, Woods Hole Oceanographic Institution, Woods Hole, \\ Massachusetts 02543, USA
}

\begin{abstract}
Hong Kong's coastal waters afford a marginal environment for coral reef growth, with high seasonal and short-term variability in water temperatures (ranging from $<14^{\circ} \mathrm{C}$ in winter to $31^{\circ} \mathrm{C}$ in summer), and low summer salinity (as low as $15 \mathrm{psu}$ ) due to runoff associated with the Asian wet monsoon season and the Pearl River Delta. Yet Hong Kong hosts 84 reef-building coral species in 28 genera of 12 families of the Scleractinia, distributed in 5 broad communities with strong geographic and environmental affinities and key indicator species. Coral communities farthest from the influence of the Pearl River Delta have relatively high sea bed coverage and species diversity (30 to $50 \%$ coverage, and $>30$ spp. per site), and also host some large, old corals. X-radiographs of a core of one massive Porites colony confirms $\sim 200 \mathrm{yr}$ of growth, with 2 short-term periods of mortality, hidden in the skeleton by overgrowth. Very low linear extension rates $\left(<4 \mathrm{~mm} \mathrm{yr}^{-1}\right)$ in this coral and 2 others are anomalous for Porites corals and are indicative of the high-stress environment. Low growth rates suggest that other Hong Kong corals, despite the harsh environmental conditions, may also live for centuries, contributing to the development of 'incipient reefs'.
\end{abstract}

KEY WORDS: Hong Kong $\cdot$ Long-lived massive corals $\cdot$ Porites $\cdot$ South China Sea

Resale or republication not permitted without written consent of the publisher

\section{INTRODUCTION}

Rapidly changing environmental conditions worldwide over the next centuries are likely to include increasing extremes in sea surface temperatures (SST) and significant changes in ocean chemistry that may push many coral reefs and communities to the margins of their environmental tolerances (Kleypas et al. 1999a, Guinotte et al. 2003). One key to understanding how coral reefs and communities may cope in the future is to study the growth history of corals that persist in environments already subject to variable and stressful conditions (Kleypas et al. 1999a). Although 'optimal' conditions for coral reef growth are commonly associated with areas of shallow, clear waters at low latitudes, many reefs and coral communities at these latitudes are associated with sub-optimal conditions and hence are termed as 'marginal' (Wicks et al. 2010). Generally in these locations corals exist close to one or more of their survival thresholds of water temperature, light penetration and aragonite saturation (Kleypas et al. 1999a). Additionally, areas of high sedimentation or upwelling can cause microenvironments with suboptimal conditions even in tropical areas (Perry 2003).

Marginal coral communities are generally characterized by limited biological diversity, absence of carbon- 
ate framework, slow or stunted growth rates, and decreased depth distribution (Harriott \& Banks 2002). The lack of framework in these communities is primarily attributable to a lack of significant calcium carbonate accretion (Buddemeier \& Smith 1999, Kleypas et al. 1999b). In many instances corals in these communities attach to hard substrata as isolated colonies growing on exposed bedrock (e.g. Macintyre 2003). Although coral communities can have species diversity similar to that of true coral reefs (>140 spp. in the Indo-Pacific region; Sheppard \& Sheppard 1991, Perry 2003), most have much lower species diversity (<90 spp.; Harriott \& Banks 2002, Moyer et al. 2003, Nozawa et al. 2008).

One such marginal environment hosting coral communities is the area around Hong Kong. Hong Kong $\left(22^{\prime} 20^{\circ} \mathrm{N}, 114^{\prime} 11^{\circ} \mathrm{E}\right)$ lies on the southern Chinese coast, in the tropics, some $320 \mathrm{~km}$ south of the Tropic of Cancer (Fig. 1). Hong Kong waters experience a range of temperatures (from 14 to $31^{\circ} \mathrm{C}$ ) and salinities (typically 24 to 25 practical salinity units, or psu, comparable to ppt) generated by the interplay of the monsoonal systems, changing ocean currents, and freshwater discharge (Tang \& Ni 1996, Lee \& Liu 1998). Hence the coral communities of Hong Kong are living at the edge of their physiological tolerances (e.g. Veron 1995, Harriott 1999). Episodic widespread par-

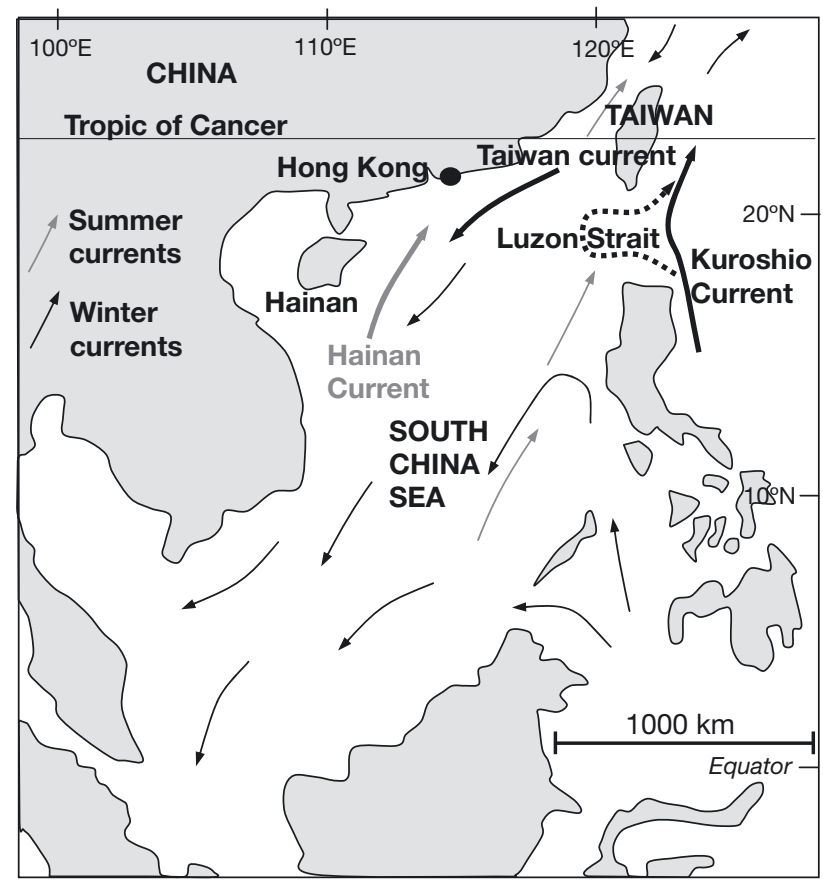

Fig. 1. Map showing the prevailing ocean currents surrounding Hong Kong. Summer waters are influenced by the Hainan current and more strongly by the heavy rains associated with the summer monsoon. Winter waters are influenced by the Taiwan Current, which can extend as far as Hainan Island. Based on Guan \& Fang (2006) tial-to-total colony mortality and localized community mortality of corals and other tropical marine species are observed at meteorological or oceanographic extremes (e.g. precipitation events or sea surface temperature [SST] minima; McCorry 2002). Hence it was considered that corals in these waters would generally be short-lived, rather than long-lived, a result of episodic mortality associated with environmental extremes and other disturbances operating on annual to decadal time scales.

This paper presents the results of a Rapid Environmental Assessment (REA) study evaluating the composition and distribution of coral species in the marginal environment of Hong Kong waters. The REA identified for the first time at this location colonies of significant age (10 to $50 \mathrm{yr}$ ), leading to a study of coral growth rates and life span. In addition, the growth rates of 3 Porites corals and the growth history of one massive Porites coral are reported and compared with those of other coral communities found in marginal environments.

\section{Coral communities of Hong Kong}

Early studies documenting coral diversity in Hong Kong mentioned 50 to 63 scleractinian species (e.g. Trott \& Fung 1973, Veron 1980, Scott 1991, Morton 1994). These non-reef-forming corals consist of typical families of the Indo-Pacific region, including Faviidae, Poritidae, Dendrophylliidae, and Acroporidae. Today, 84 species of scleractinian corals have been identified, from 28 genera in 12 families (DeVantier \& McCorry 2003, Chan et al. 2005). Coral communities are primarily located outside the influence of the Pearl (Zhujiang) River Delta in the eastern waters of Hong Kong (Fig. 2), with the largest and most diverse populations in the northeast at Mirs Bay, far from the delta. Included in these populations are the massive life-forms of the scleractinian species Porites lobata and P. lutea, whose skeletons are an important resource for studying past climate and pollution changes (e.g. Barnes \& Lough 1996,Alibert \& McCulloch 1997, Gagan et al. 2000, Lough 2010).).

Despite the presence of reef-building corals, there is no evidence of prolonged reef accretion in Hong Kong; there are no documented relict structures, uplifted limestone, or fossil reefs (McCorry 2002). Due to this lack of extant carbonate platforms, the physically challenging environment, and the cumulative impact of a significant coral-based lime industry in the early 20th century, it was commonly believed that long-lived (multi-century) massive corals did not occur in Hong Kong waters (Morton 1995). Such live or sub-fossil colonies might provide a wealth of geochemical evi- 


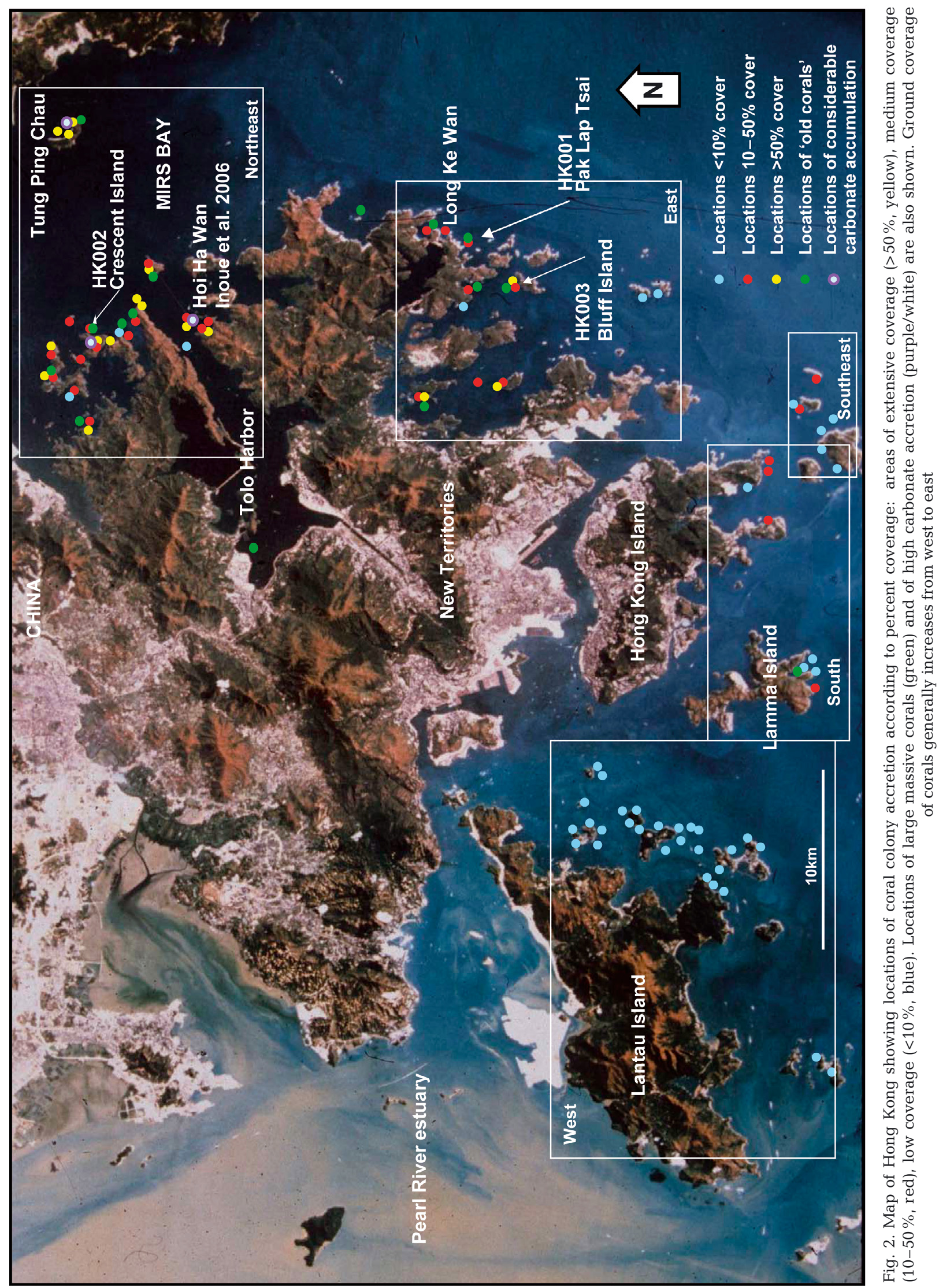


dence, allowing for the study of land use, pollution, and climate change along the coast of southern China. The South China Sea and Hong Kong waters in particular have been and will continue to be a region of rapid human expansion over the next decade (Wilkinson et al. 2005), making this a critical location for evaluating the marine impacts of pollution, changes in the water cycle, and changes in climate.

\section{Environmental setting}

The landmass of Hong Kong is composed of more than 235 islands and a small section of mainland China (New Territories), with $1656 \mathrm{~km}^{2}$ of associated coastal waters (Fig. 1; Morton 1996). The eastern and southern coasts of Hong Kong are exposed episodically to cyclonic southerly winds and storm waves from the South China Sea (Yim 1992, Wang 1997). In contrast, the western and northwestern coasts are more sheltered from the action of monsoon-wind-driven waves, although these areas can experience small waves from northerly winds in winter (Wang 1997).

The monsoon-dominated weather system and proximity to the Asian landmass lead to relatively large seasonal temperature ranges in both air $\left(16\right.$ to $\left.29^{\circ} \mathrm{C}\right)$ and sea water $\left(14\right.$ to $31^{\circ} \mathrm{C}$; Tang \& Ni 1996, Lee \& Liu 1998), as well as seasonally low salinity (28 psu) due to freshwater flux (Lee \& Liu 1998). The complex hydrography makes it a naturally challenging environment for coral growth. In addition, Hong Kong is a highly developed and populated city, with considerable outputs of contaminants, as recorded by high levels of metals in coral tissue (McCorry \& Blackmore 1998, McCorry 2002). Anthropogenic inputs are exacerbated by land reclamation activities (Scott 1990, Leung \& Morton 1997) that have led to the extirpation of coral communities in some locations (McCorry \& Blackmore 1998).

The western waters of Hong Kong are strongly influenced by the Pearl River Delta. On average, the Pearl River discharges $3.0 \times 10^{11} \mathrm{~m}^{3}$ of water and $83.4 \times 10^{6}$ of suspended sediment a year, making it one of the smallest discharges among large Asian rivers (Zong et al. 2009). Nevertheless, the variable monsoon climate causes major seasonal and interannual variability in discharge, ranging from as low as $2000 \mathrm{~m}^{3} \mathrm{~s}^{-1}$ in a dry winter to as high as $46300 \mathrm{~m}^{3} \mathrm{~s}^{-1}$ recorded in a 100-yr flood event (Huang et al. 2004). The river discharge can drastically reduce salinities along Hong Kong's western coast to as low as 1.3 psu (Morton \& Wu 1975). Moreover, it bears a large sediment load (Fig. 2), which can lead to a stratified, estuarine coastal water column as river water and sea water mix (Watts 1971).
In contrast, the eastern waters of Hong Kong are predominantly marine and sheltered from the influence of the Pearl River. However, during the summer, the eastern coast is influenced by heavy rains and local runoff that can lower in-shore salinities to 25 psu (Lee \& Liu 1998).

\section{MATERIALS AND METHODS}

Coral field surveys. Coral communities along $\sim 72 \mathrm{~km}$ of coastline in the waters of Hong Kong were surveyed during 2001 and 2002 using standardized methods (after Chiappone \& Sullivan 1991, DeVantier et al. 1998). This study was reported to the Hong Kong government (DeVantier \& McCorry 2003) and is reported for the first time in the literature here. Study sites were selected in a representative range of locations, to survey a range of oceanographic and geographic features and distances from the Pearl River Delta (Fig. 2).

Surveys were conducted in 3 stages: Spot-check Reconnaissance Dives, REA, and Quantitative Video Transects. Initial spot-check dives were conducted as a reconnaissance tool for assessing sites supporting coral communities in extremely turbid waters $(<1 \mathrm{~m}$ underwater visibility). A total of 141 spot dives were carried out in the western and eastern waters between September and December 2001, covering approximately $48 \mathrm{~km}$ of sublittoral communities. Locations of all spot dives were noted (GPS position) and the major benthic components were recorded (see full report in DeVantier \& McCorry 2003). This method allowed prioritization of the more detailed coral bioinventory REA and video surveys in those areas supporting coral communities.

Subsequent detailed REA dives were then conducted in suitable sites between September and January, when conditions, including water clarity, were optimal. REA methods have been developed to provide highly informative baseline information on many coral regions, including the Florida Reef Tract (Chiappone \& Sullivan 1991), Palau (Maragos \& Cook 1995), the Great Barrier Reef (DeVantier et al. 1998) and the Red Sea (DeVantier et al. 2000). The REA method developed for the Indo-Pacific was refined for use in local waters, and standardized methods were employed for the dive surveys (DeVantier \& McCorry 2003). This study was the first effort to specifically identify areas with 'old corals', which are defined as colonies appearing to have been accreting for a period of many decades to centuries, and which were at least $0.5 \mathrm{~m}$ in diameter. Follow-up surveys conducted by J.D.T. in 2007 identified old corals in additional locations. 
In total, approximately $24 \mathrm{~km}$ of REA surveys were completed (142 sites over $14.2 \mathrm{~km}$ from September to November 2001). The field data were gathered by swimming (with SCUBA) down-current along coral communities or along identified sections of coastline from randomly chosen starting points, and were recorded by observers (D.M. and L.D.) experienced in the underwater identification of sessile benthic taxa. To facilitate standardization of the method, the observers surveyed areas of approximately $100 \mathrm{~m}^{2}$ at each site, i.e. belt transects $1 \mathrm{~m}$ wide $\times 100 \mathrm{~m}$ long. Each transect was positioned within a single depth range, such that each 'site' was in a particular ecological zone or habitat. Each belt transect comprised a $1 \mathrm{~m}$ swath of seabed (dependent on visibility) $\sim 0.5 \mathrm{~m}$ away from the transect tape to maintain independent transects. At least 2 belt transects were surveyed at each location, one on each side of the transect tape. Where the communities were sufficiently well developed, additional transects were surveyed. Start-points of the surveys were recorded with a portable GPS unit. Surveys along each transect took between 30 and $60 \mathrm{~min}$ to complete. The surveys covered most of the coral community at each site, and the sites were all large enough to encompass the main characteristics of each coral community. Two types of information were recorded during each transect survey: (1) an assessment of the relative cover of the major benthic groups, and (2) an inventory of sessile benthic taxa.

Finally, 10 key locations identified from the REA surveys were chosen for quantitative video transects. These sites provided a representative set of the healthiest coral communities in Hong Kong waters at the time, and transects were placed within the best coral areas of the sites. This standard quantitative survey method provided precise quantitative estimates of coral cover and abundance of common benthic taxa, essential as a baseline for long-term monitoring. The method is also relatively straightforward in terms of field methods (e.g. Wachenfeld 1996), and has provided a permanent video record of the study sites. The video footage was analyzed at genus level for all Scleractinia and to species level for common well defined taxa.

Coral collection and analysis. Two cores, each $0.7 \mathrm{~m}$ long and $5 \mathrm{~cm}$ in diameter, were collected from massive Porites lutea corals. In June 2008 one coral core was collected from $9 \mathrm{~m}$ depth at Pak Lap Tsai (HK001) and in May 2010 a second coral core was collected from $2 \mathrm{~m}$ depth at Crescent Island (HK002; Fig. 2). In February 2010 an additional short core $(\sim 10 \mathrm{~cm}$ long) from a $P$. lutea colony was taken from $3 \mathrm{~m}$ depth at Bluff Island (HK003). In early winter 2007, HK001 was identified and observed to be living, but by June 2008, the top of the colony had died, likely a result of the $13^{\circ} \mathrm{C}$ sea water temperatures in January 2008 (Environmental Protection Department [EPD] of Hong Kong SST data).

The cores were collected using SCUBA and a stainless-steel, pneumatic coring device. A $1 \mathrm{~cm}$ thick slab was cut from the coral cores, cleaned with deionized water and dried. X-radiographs were performed at the Central Medical Diagnostic Center in Hong Kong. HK001 and HK002 were also scanned via Computerized Axial Tomography (CAT; Fig. 3) at the University of Hong Kong Queen Mary Hospital. The CAT scan of HK001 was taken at a $45^{\circ}$ offset from the growth direction of the core. This was done to evaluate a portion of the core in which the primary growth axis was not visible in the X-ray.

Age models were developed by counting high-low density banding visible in the coral X-ray and CAT scan, and were confirmed using Image J, which calculates relative density along an image based on brightness. In addition, radiocarbon dating was completed on HK001. To help constrain 2 periods of die-off apparent in the core, dating was performed on 1 sample from the bottom of the core and on 3 samples at each side of both junctions of the 2 mortality events (12 samples total). These measurements were performed at the University of California-Irvine Accelerator Mass Spectrometer facility.

Environmental data. Physical-chemical water quality data were collected from the marine water quality database maintained by the EPD (http://epic.epd.gov. hk/ca/uid/marinehistorical/p/1). Publicly available data from 2000 to 2008, at monthly resolution, were downloaded from sites representing the 5 geographical regions of Hong Kong (Table 1). For the period from 2000 to 2008, the mean annual minimum and maximum $\mathrm{pH}$, salinity and turbidity values, as well as average annual values, were calculated from surface and mid-depth measurements. These parameters were chosen due to their strong correlation to hard-coral diversity found in this study. In addition, 4 sites in proximity to the coral cores were selected to evaluate proximal temperature, salinity, and turbidity ranges in which the corals grew.

\section{RESULTS}

REA surveys revealed that coral diversity and accretion correlate to the gradual transition of the coastal waters from limited coral cover in the west to greatly increased coral cover along the eastern shoreline, as explained below. Old Porites colonies were also found primarily in the eastern waters outside the influence of the Pearl River Delta, where salinities are higher and sediment loads lower than in the west (Fig. 4). 
A Top

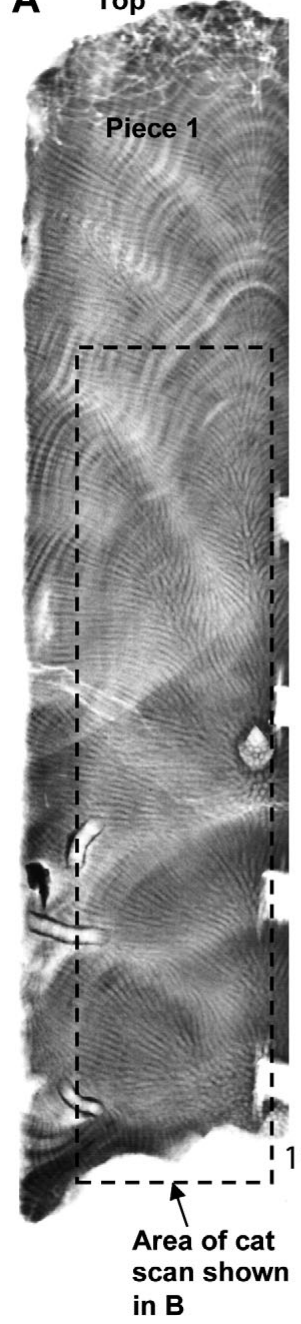

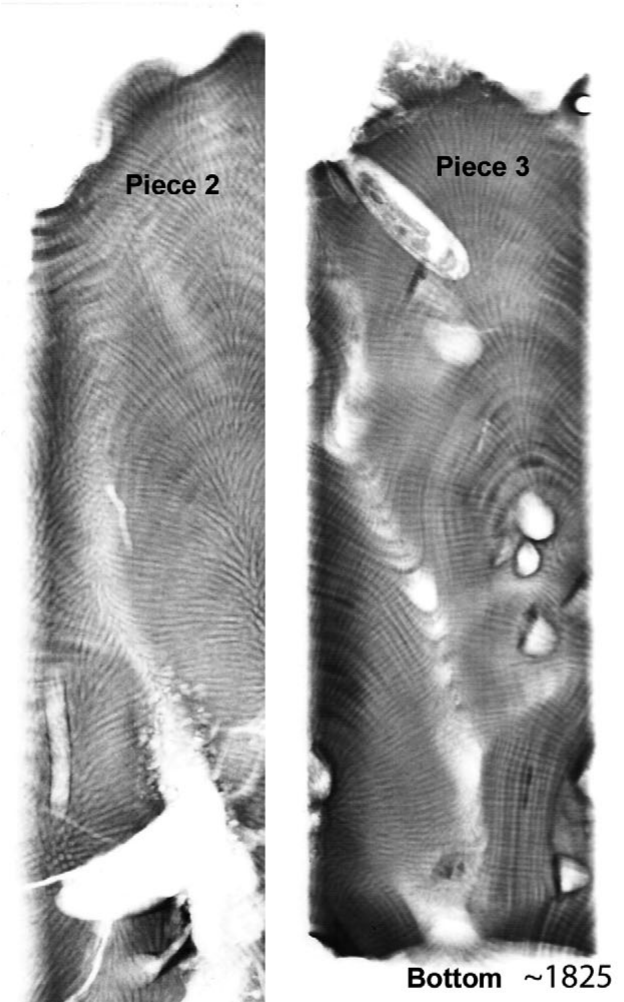

B

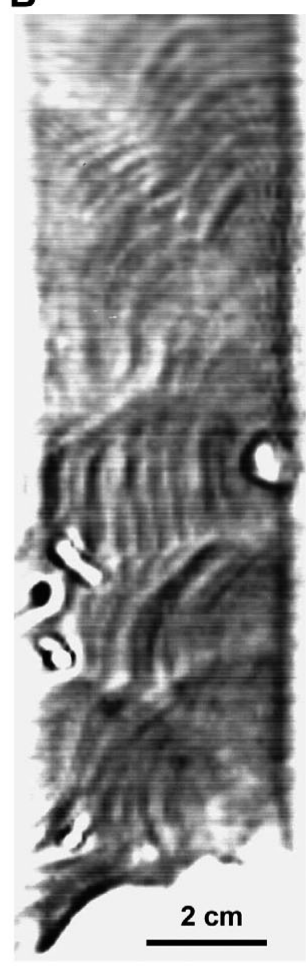

Table 1. Environmental Protection Department (EPD) sites for regional analysis

\begin{tabular}{|ll|}
\hline Region & EPD sites \\
\hline West & SM: 9, 10,11,12,13,17, 20 \\
South & SM: 1,6,7,18 \\
South East & SM:19 and MM: 8, 14 \\
East & PM: 3, 7, 8, 9 and MM:15, 16 \\
North & MM: 2, 3, 4, 5, 6, 7, 17 and TM: 8, 17 \\
Source: http://epic.epd.gov.hk/ca/uid/marinehistorical/p/1
\end{tabular}

\section{REA, coral community structure and ecological status}

The REA indicated that coral communities found in Hong Kong waters form incipient reefs with substantial biogenic accretion, but no reef flats. Of the 240 REA sites investigated, the majority were either incipient reefs $(24 \%)$ or coral communities that developed directly on rock, sand or rubble with little to no accretion $(26 \%)$. A further $41 \%$ had sparse coral growth, while at the remaining sites $(9 \%)$ no hard corals were present. Significant trends in the geographic location of coral growth were found, with incipient reefs mostly developed in northeast and eastern waters (97\% of all incipient reefs).

Coral communities were more widely distributed than incipient reefs, comprising $39 \%$ of northeast sites, $52 \%$ of eastern sites, $100 \%$ of southeastern sites and $60 \%$ of southern sites, whereas the vast majority of western sites had sparse corals ( $81 \%$ of sites) or no hard corals (18\% of sites). Incipient reefs and coral communities were generally developed from low-tide level to $\sim 12 \mathrm{~m}$ depth, with most occurring in depths of 1 to $6 \mathrm{~m}$. The regions of growth were focused on gentle slopes $\left(<10^{\circ}\right.$ to the horizontal), most often surrounded by sand and silt, transitioning to carbonate-derived sand at depth. Some exceptions included sites where incipient reefs and coral communities were of small extent $(<1 \mathrm{ha})$, and usually occurred in sheltered and semi- 


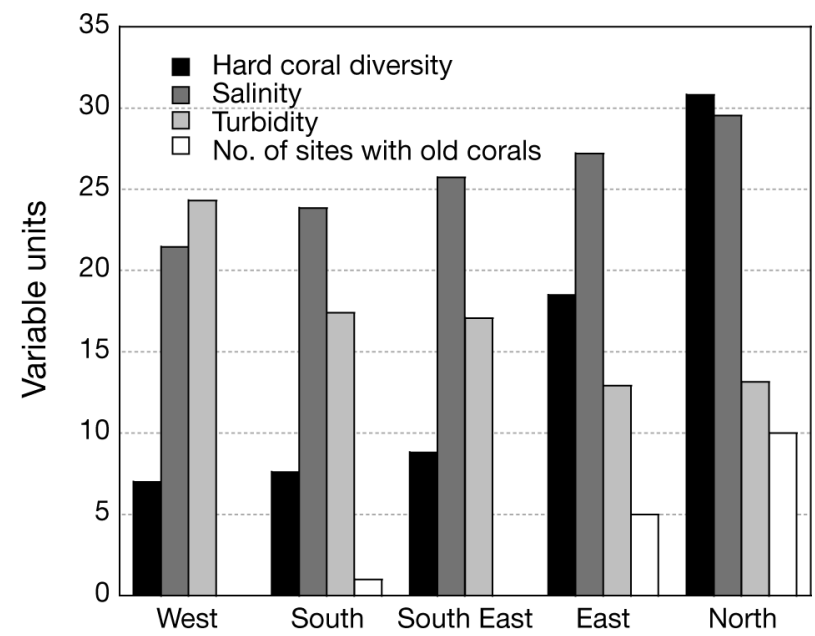

Fig. 4. Hard coral diversity (average numbers of species among sites in each region), salinity (practical salinity units), turbidity (nephelometric turbidity units), and number of sites with old corals, by geographical region

sheltered environments. These deeper reef communities reflect the clarity and generally good water quality at these locations. Although no large reef flats are present in Hong Kong waters, some sites have a considerable amount of carbonate accretion (e.g. Tung Ping Chau, Hoi Ha Wan 'Coral Beach' and Bluff Island) (Fig. 2).

Most sites assessed during the REAs were in relatively good condition, with low cover of dead corals $(<5 \%)$, low average levels of injury per species (90\% of sites with $<25 \%$ average injury) and low proportions of species with injury ( $84 \%$ of sites with $<25 \%$ of spp. injured). Coral cover was highest in the northeast and east (30 to $50 \%$ ), with intermediate cover found in the southeast and south (10 to $30 \%$ ), and the lowest coral cover recorded in the west $(<5 \%$, and usually $<1 \%)$. With regard to species diversity, the REA results indicated that Hong Kong has a much richer hard-coral fauna than was known previously (Veron 1980, Scott 1991, Morton 1994). The REAs were the basis for the subsequent confirmation of the presence of some 84 species in 28 genera of 12 families of the Scleractinia, including 2 undescribed species, a poritid, Goniopora sp., and a siderastreid, Coscinaraea sp. (J.E.N. Veron, pers. comm.). In keeping with trends of reef development and coral cover, the highest diversity occurred in eastern and northeastern waters (generally >30 coral spp. per site), with intermediate levels of diversity in southeastern and southern waters (usually from 20 to $30 \mathrm{spp}$.). By comparison, western waters exhibited low diversity ( $<20$ species).

The spot-checks and REAs identified 5 major community types (see full details in DeVantier \& McCorry 2003), with strong geographic and environmental affinities and key indicator species: Platygyra-Favia dominated communities were generally found in the clear sheltered waters of the east and northeast at sites with low turbidity, low sediment and high salinity; Acropora solitaryensis-Montipora peltiformis communities occurred in the more exposed areas of the east, southeast and south, and were characterized by moderate to high water clarity and salinity, and low sediment; Psammocora communities were associated with the more turbid and lowersalinity conditions found in the south and west; PoritesCyphastrea communities usually occurred in deeper waters to the northeast and south at sites with moderate water clarity and sediment deposition; soft coral-mollusc communities were present in the west and southeast at sites with consistently low water clarity, low salinity and higher levels of sediments.

Mean site-level scleractinian species diversity increased from 7 to 30 from west to east, a trend consistent with an increase in salinity, $\mathrm{pH}$, turbidity and the number of sites with old corals (Table 2). The mean annual $\mathrm{pH}$ from 2000 to 2008 showed the most significant correlation with coral diversity $(\mathrm{r}=0.85, \mathrm{p}=0.07)$. Turbidity and salinity also correlated well to hard-coral diversity $(\mathrm{r}=$ $0.54, \mathrm{p}=0.21$ and $\mathrm{r}=-0.68, \mathrm{p}=0.28$ respectively).

\section{Long-lived corals}

Large beds, stands or individual coral colonies that might represent many decades to a century of growth ( $>0.5 \mathrm{~m}$ in diameter) were characteristic of some sites, notably in eastern waters (Fig. 2). Such corals were typically of massive growth-form, including Platygyra, Porites, Favia, Favites, Acanthastrea and Goniopora, but also include branching corals such as Pavona, Echinophyllia and Montipora.

\section{Coral growth patterns}

\section{HK001}

Analysis of the coral core HK001, from Pak Lap Tsai, indicated that the colony had been living for more than 180 yr. The core was interrupted by 2 distinct periods of die-off, which resulted in the core being broken into 3 pieces. The die-off represents episodes of partial mortality to the colony, followed by re-growth across the dead surfaces (e.g. DeVantier \& Done 2007). The most recent re-growth exhibits no visible sediment and minimal aragonite alteration. There is a clean joint between the core pieces, with a singular growth axis direction. The previous die-off appears to have taken longer to 'heal', as visible diagenesis has occurred over $0.5 \mathrm{~cm}$ at the top of piece 3 (Fig. 3). In addition, there was one large borehole in the middle piece, likely the result of a bio-eroding species, possibly Lithophaga (Fig. 3). 
Table 2. Hard-coral diversity (average number of species amongst sites in each region), pH, salinity, turbidity and number of sites with old corals by geographic region. Data averaged from 2000 to 2008

\begin{tabular}{|lcccccccc|}
\hline $\begin{array}{l}\text { Geographical } \\
\text { area }\end{array}$ & $\begin{array}{c}\text { Hard coral } \\
\text { diversity }\end{array}$ & $\begin{array}{c}\mathrm{pH} \\
\text { range }\end{array}$ & $\begin{array}{c}\mathrm{pH} \\
\text { average }\end{array}$ & $\begin{array}{c}\text { Salinity } \\
\text { range (psu) }\end{array}$ & $\begin{array}{c}\text { Salinity } \\
\text { average }\end{array}$ & $\begin{array}{c}\text { Turbidity } \\
\text { range (NTU) }\end{array}$ & $\begin{array}{c}\text { Turbidity } \\
\text { average }\end{array}$ & $\begin{array}{c}\text { Sites with } \\
\text { old corals }\end{array}$ \\
\hline West & 7.0 & $7.8-8.5$ & 8.1 & $21.5-31.4$ & 30.3 & $5.6-24.3$ & 12 & 0 \\
South & 7.6 & $7.8-8.5$ & 8.2 & $23.8-33.2$ & 31.1 & $3.9-17.4$ & 9 & 1 \\
Southeast & 8.8 & $7.9-8.5$ & 8.2 & $25.7-34.1$ & 32.5 & $3.4-17.1$ & 8 & 0 \\
East & 18.5 & $7.9-8.5$ & 8.2 & $27.2-33.6$ & 32.5 & $3.2-12.9$ & 7 & 7 \\
North & 30.8 & $7.9-8.5$ & 8.2 & $29.5-33.5$ & 32.2 & $3.3-13.1$ & 7 \\
Source: http://epic.epd.gov.hk/ca/uid/marinehistorical/p/1 & & & & \\
\hline
\end{tabular}

X-radiograph positives of the coral core revealed that the primary growth axis covered the length of the core, with the exception of the bottom of Piece 1 (Fig. 3A). In this case, the CAT scan at $45^{\circ}$ relative to the left of the plane of the core revealed growth bands in the entire piece of the core, showing the same results as the X-ray in the top portion (Fig. 3B). This confirms the growth rates over most of the lower portion. The bottom $51 \mathrm{~mm}$ were difficult to resolve accurately. For the purpose of age model development, the average growth rate of the colony was applied to estimate years within this section.

The $70 \mathrm{~cm}$ coral core had an average growth rate of $3.2 \mathrm{~mm} \mathrm{yr}^{-1}$ (range of from 1.3 to $7.1 \mathrm{~mm} \mathrm{yr}^{-1}, \mathrm{SD}=$ $0.9 \mathrm{~mm} \mathrm{yr}^{-1}$ ). Age model error was estimated to be \pm 1 to $5 \mathrm{yr}$, with error increasing with depth. This resulted primarily from counting error or from years not visible in the X-ray due to little or no growth. Difficulty resolving the lowest portion of Piece 1 likely increased age model error for this depth and below to a minimum of $\pm 2 \mathrm{yr}$, or slightly $>10 \%$ of the years in the irresolvable period. Based on counting, the skeleton contains $182 \mathrm{yr}$ of coral extension. Piece 1 grew from 1942 to 2008. Piece 2 grew for $68 \mathrm{yr}$, and the bottom portion represents an additional 48 yr of growth.

Radiocarbon dating was employed to estimate the time periods of die-off that impacted this location in the coral colony. The bottom of Piece 1 was estimated to have grown in $1942 \pm 3$ yr based on band counting. Three sequential radiocarbon dates reveal an average value of ${ }^{14} \mathrm{C}$ of 570 . This implies a delta $\mathrm{R}$ in this region of +110 , as the Marine04 calibration value for 1942 is 460 (Hughen et al. 2004, Reimer et al. 2004). A previous study on a mollusk from Hong Kong waters reported a delta $\mathrm{R}$ of +167 (Southon et al. 2002), but, unlike the coral, the mollusk did not have a known calendar age.

The remaining radiocarbon dates were therefore assigned a delta $\mathrm{R}$ of +110 and then matched to the Marine04 data to estimate the calendar dates. The top of Piece 2 had an average raw ${ }^{14} \mathrm{C}$ value of 558 or a reservoir-corrected ${ }^{14} \mathrm{C}$ of 448 ; the bottom of Piece 2 returned an average raw ${ }^{14} \mathrm{C}$ value of 569 or a reservoir-corrected ${ }^{14} \mathrm{C}$ of 459 . Between these 2 dates the coral grew for 68 yr. Combining the known period of growth of the coral and the best fit to the Marine04 curve provided the bottom of Piece 2 with a date of $\sim 1870$. The raw ${ }^{14} \mathrm{C}$ value for the top of Piece 3 was 597 or a reservoir-corrected ${ }^{14} \mathrm{C}$ of 487 , and the bottom of the core had a raw ${ }^{14} \mathrm{C}$ value of 590 (reservoircorrected 480). The coral grew for $48 \mathrm{yr}$ between these dates, providing a best-fit date at the bottom of the coral of 1825. This represents a total of $183 \mathrm{yr}$ of coral growth. By counting, we determined that the coral skeleton extended over $182 \pm 5 \mathrm{yr}$, which is in agreement with the radiocarbon age. While errors on radiocarbon dates can be large $( \pm 35 \mathrm{yr})$, the agreement between the counting and the radiocarbon dates supports the conclusion that the die-offs experienced in this region of the colony were short $(<5 y r)$ and that we are not missing large periods of time in our chronology. Given limited sediment accumulation, bioerosion and a constant growth axis at the latest connection point, it was more likely that the recent die-off lasted less than 2 or 3 yr. The earlier die-off was likely to have lasted longer, as demonstrated by the diagenesis.

\section{HK002}

HK002 is a continuous core with no colony mortality over its complete $0.7 \mathrm{~m}$. The colony was roughly $1 \mathrm{~m}$ in height. Based on periods of visible growth axis, the coral grew roughly 4 to $4.5 \mathrm{~mm} \mathrm{yr}^{-1}$ over $8 \mathrm{yr}$ and closer to $5 \mathrm{~mm} \mathrm{yr}^{-1}$ over $3 \mathrm{yr}$. Unlike HK001, this colony changed growth directions repeatedly, making the development of a full growth history infeasible as the primary growth axis was not always resolvable even using a CAT scan at varying angles. We estimate, based on size and growth rate, that this coral has lived for longer than $200 \mathrm{yr}$.

\section{HK003}

A short $(10 \mathrm{~cm})$ core from the top of HK003, a $0.5 \mathrm{~m}$ colony, showed average growth rates of $4.5 \mathrm{~mm} \mathrm{yr}^{-1}$ over $5 \mathrm{yr}$, providing an estimated colony age of $100 \mathrm{yr}$. 


\section{DISCUSSION}

\section{Coral communities}

The presence of widespread growth of corals in some areas of Hong Kong waters - notably the northeastern, eastern and southeastern areas - with absence of major reef accretion, is consistent with other marginal reef environments, such as the Arabian Sea, eastern Pacific and other sub-tropical localities (Veron 1986, Sheppard et al. 1992, Wicks et al. 2010)). This 'uncoupling' of coral growth from reef development has been attributed to failure of sedimentary lithification processes for unknown reasons (Behairy et al. 1992).

The lack of reef accretion around Hong Kong is likely attributable to the interaction of some or all of the following factors: recurrent mass coral mortality related to extreme temperature, salinity and/or turbidity; fluctuations linked with winter cold fronts or flooding; competition with macro-algae; episodic burial under soft sediments (possibly exacerbated by benthic trawling); slow coral growth rates; high rates of bioerosion (Buddemeier \& Smith 1999, Kleypas et al. 1999a, Lough \& Barnes 2000). In marginal coral reef settings considered globally, Hong Kong and the Persian Gulf have the largest range of SSTs, while Hong Kong and Japan have some of the lowest SST values (Fig. 5). These conditions may significantly impact the rate of carbonate accretion either directly or through organism interactions. For comparison, on some cool-water eastern Pacific reefs, bioerosion (primarily by sea urchins and parrot fish) can exceed carbonate deposition (Glynn 1988). Notably, high populations of urchins (mostly Diadema, Anthocidaris, Parasalenia and Salamaris spp.) were present at some Hong Kong sites, including Long Ke Wan. Snail predation was apparent, particularly at Bluff Island. A longer-term study is required to assess the full impact of bioeroders in Hong Kong.

A further possibility explaining the lack of reef building is the late initiation of coral recruitment and reef growth (over the past several millennia), as conditions for supply of coral larvae and/or coral growth became progressively more favorable. Notably, there is no evidence of earlier periods (e.g. Pleistocene) of coral and reef growth in the region, as determined by the presence of relict 'spur and groove' structures, uplifted limestones or fossil reefs, apart from a small area of Permian-dated sedimentary deposits with fossil corals at Tolo (Yim et al. 1981). The major findings of the REA are that low coral diversity, low coral accretion and variation in coral communities based on location are all found within Hong Kong waters.

The range of $\mathrm{pH}$ and salinity within each of the 4 REA geographical regions is larger than the range

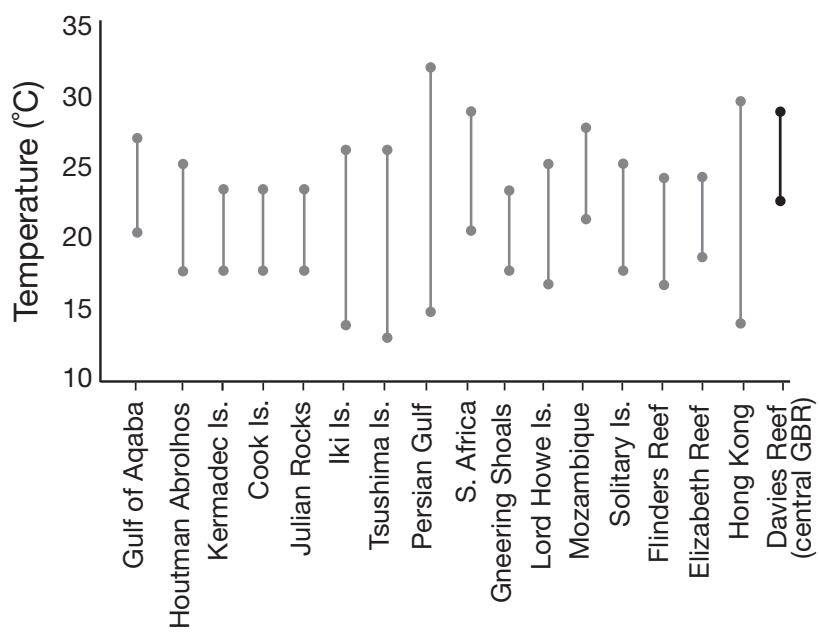

Fig. 5. SST ranges for marginal reefs and communities (grey bars) and a non-marginal reef (black bar) adapted from Wicks et al. (2010). Data from www.reefbase.org/gis_maps/ download.aspx, Yamano et al. (2001), and the EPD (http:// epic.epd.gov.hk/ca/uid/marinehistorical/p/1)

between regions, indicating that the minimum $\mathrm{pH}$ and minimum salinity may be important for coral communities in Hong Kong (Table 2). In evaluating conditions for coral growth, extremes are as important as annual or decadal averages.

\section{Coral growth rates}

Linear extension rates in the 3 Hong Kong corals show colony growth rates to be well below the average growth rates reported for Porites corals, which generally grow more than $8 \mathrm{~mm} \mathrm{yr}^{-1}$ in tropical locations (e.g. Alibert \& McCulloch 1997, Hughen et al. 1999, Lough \& Barnes 2000, Marshall \& McCulloch 2002). This is consistent with a physiologically stressful environment, and the lack of a consistent major growth axis in HK002 is indicative of the environmental 'challenge' that corals in Hong Kong are facing. However, a previously published Porites X-ray (Inoue et al. 2006) for a sample collected from Hoi Ha Wan in the 1990s shows growth rates close to $10 \mathrm{~mm} \mathrm{yr}^{-1}$. Thus, corals within Hong Kong waters appear to have a large range of growth rates amongst, though seemingly not within, colonies, as all 4 cored colonies show consistent rates of growth through time.

Extension rates in corals have been linked to several factors, including SST (Lough \& Barnes 1997, 2000), nutrient availability (Edinger et al. 2000, Lough \& Barnes 2000, Carilli et al. 2009), light intensity (Kawaguti 1937, Yonge 1963, Lough \& Barnes 2000), and turbidity (Done 1982, Edinger et al. 2000, Carilli et al. 2009). A large range of physical conditions is found in 
Hong Kong coastal waters (Tables 2 \& 3), typical of a coastal site adjacent to the mouth of a major river.

The coral core site locations show no strong geographical gradient in temperature, salinity or turbidity (Table 3). All 4 sites have relatively similar temperatures, though Hoi Ha Wan, which has the coral with the fastest growth rate, has the warmest average temperature (by $\sim 0.5^{\circ} \mathrm{C}$ ). Turbidity at each site showed a large decadal range (Table 3). Hoi Ha Wan has the lowest range of turbidity, which may also contribute to the faster growth rate of the Porites coral there. No significant trend was found amongst the sites for $\mathrm{pH}$ and nutrient loading, and the 2000 to 2008 averages amongst the sites were relatively consistent.

A useful comparison can be made of our results with those of Lough \& Barnes (2000) and Lough (2008), who derived a relationship between annual coral extension and mean annual SST for colonies living in mean annual temperatures of 23.2 to $28.8^{\circ} \mathrm{C}$ :

$$
\text { Extension rate }=2.975(\mathrm{SST})-65.459
$$

where extension rate is the mm vertically accreted in a 1 yr period, as measured by X-radiographs and gamma densitometry, and SST is mean annual SST. Average mean annual SST for 2000 to 2007 at Pak Lap Tsai (MM15) and Bluff Island (PM11), including surface and mid-depth, is $23.1^{\circ} \mathrm{C}$. By Eq. (1), extension (growth) rate over this period would be $3.3 \mathrm{~mm}$ $\mathrm{yr}^{-1}$ The average extension rate found in HK001 (Pak Lap Tsai) for this period is $2.5 \mathrm{~mm} \mathrm{yr}^{-1}$ and for HK002 (Bluff Island), $4.5 \mathrm{~mm} \mathrm{yr}^{-1}$, within the scatter found by Lough \& Barnes (2000; Fig. 6). However, Inoue et al. (2006) did not find growth rates that fit this curve, which may mean that temperature is not the only factor impacting growth rate in Hong Kong coastal waters.
The low temperatures as well as the low salinities may lead to interruptions in growth in both summer and winter (Veron 1995, Harriott 1999, Hendy et al. 2003), contributing to low skeletal extension. Large, old corals in Hong Kong waters appear at a number of locations, but the quantity at each location is very low $(<5)$. The 2 die-offs seen in HK001, representing partial mortality in the vicinity of the core, are an indication that long-lived corals succumb to environmental pressures. The coral appears to have suffered partial mortality and to have re-grown over the dead surfaces, but the constant direction of the growth axis between the slabs indicates no physical trauma, such as toppling or rolling over. Thus, while recurrent mortality has shortened the continuous growth period, it has not killed the coral outright, nor prevented re-growth, thus allowing for the accretion of calcium carbonate over more than a century.

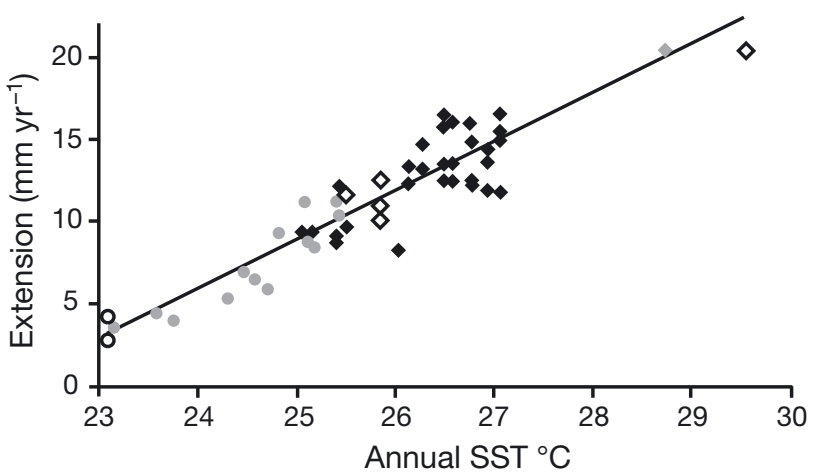

Fig. 6. Colony extension rate vs. annual SST for corals from the Hawaiian archipelago (O, Grigg 1981), Phuket, Thailand $(\diamond$, Scoffin et al. 1992), from the Great Barrier Reef $(\diamond$, Lough $\&$ Barnes 2000), from the Arabian Gulf and Lihir Island $(\diamond$, Lough 2008), and this study - Hong Kong (O). As presented in Lough (2008), the regression line includes all data except this study

Table 3. Depth, temperature, salinity and turbidity values from EPD stations closest to coral cores, with annual extension rates by colony. Data from 2000 to 2008

\begin{tabular}{|c|c|c|c|c|c|c|c|c|c|c|}
\hline Station & Location & Sample & $\begin{array}{l}\text { Depth } \\
\text { (m) }\end{array}$ & $\begin{array}{c}\text { Temp. } \\
\text { range }\left({ }^{\circ} \mathrm{C}\right)\end{array}$ & $\begin{array}{l}\text { Temp } \\
\text { avg. }\end{array}$ & $\begin{array}{c}\text { Salinity } \\
\text { range } \\
\text { (psu) }\end{array}$ & $\begin{array}{l}\text { Salinity } \\
\text { average }\end{array}$ & $\begin{array}{c}\text { Turbidity } \\
\text { range } \\
\text { (NTU) }\end{array}$ & $\begin{array}{c}\text { Turbidity } \\
\text { average }\end{array}$ & $\begin{array}{c}\text { Extension } \\
\text { rate } \\
\left(\mathrm{mm} \mathrm{yr}^{-1}\right)\end{array}$ \\
\hline \multicolumn{11}{|c|}{ Surface water } \\
\hline MM15 & Pak Lap Tsai & HK001 & 1 & $14-32$ & 23.8 & $26-34$ & 32 & $1.3-34.1$ & 8 & 3.0 \\
\hline PM11 & Bluff Island & HK002 & 1 & $14-31$ & 23.7 & $22-34$ & 32 & $1.0-21.8$ & 7 & 4.5 \\
\hline MM6 & Crescent Island & HK003 & 1 & $14-32$ & 23.7 & $26-34$ & 32 & $1.3-34.1$ & 7 & 4.5 \\
\hline MM7 & Hoi Ha Wan & Inoue et al. (2006) & 6) 1 & $15-32$ & 24.3 & $26-34$ & 32 & $0.8-17.3$ & 7 & 10.0 \\
\hline \multicolumn{11}{|c|}{ Mid-depth (measured halfway down water column at each site) } \\
\hline MM15 & Pak Lap Tsai & HK001 & 12.0 & $14-28$ & 22.4 & $31-35$ & 33 & $1.6-21.2$ & 8 & 3.0 \\
\hline PM11 & Bluff Island & HK002 & 10.5 & $14-28$ & 22.4 & $31-35$ & 33 & $1.6-21.2$ & 8 & 4.5 \\
\hline MM6 & Crescent Island & HK003 & 6.0 & $14-30$ & 23.1 & $29-34$ & 32 & $1.3-32.1$ & 7 & 4.5 \\
\hline MM7 & Hoi Ha Wan & Inoue et al. (2006) & 6) 6.5 & $14-31$ & 23.3 & $29-34$ & 32 & $0.8-17$ & 7 & 10.0 \\
\hline
\end{tabular}




\section{CONCLUSIONS}

Hong Kong has longer-lived corals than previously thought. Salinity and sediment load are the physical conditions with the largest geographical gradient across Hong Kong waters, along with species diversity. Despite critical physical challenges, including low temperatures, fresh water outflow, a strong rainy season and large sediment loads, the corals of Hong Kong are surviving in the face of increasing environmental pressures from urbanization. The growth of massive corals continues at rates as low as $30 \%$ of typical growth rates for the same species. While reef accretion has not occurred in this community, massive corals more than a century old - that accrete skeleton slowly are found in HK waters.

The existence of long-lived massive corals in Hong Kong waters opens a new research opportunity, viz. the study of the history of corals living in marginal environments. Given the exceptionally slow growth rate of some massive corals in these waters, smaller colonies previously assumed to be short-lived ( $<50 \mathrm{yr})$ may have lived more than twice that long. Further studies of the physiological tolerances of coral species, and the factors influencing rates of coral growth, reef accretion and bioerosion, should enhance our understanding of reef marginality, an increasingly important topic in this era of global climate change.

Acknowledgements. Several reviewers commented on this manuscript in detail, providing suggestions that greatly improved it. The authors acknowledge the Agriculture, Fisheries and Conservation Department, Government of Hong Kong Special Administrative Region, for assistance in permitting and funding the coral survey performed by L.D. and D.M., and we thank W. Yim for access to equipment. Funding for this project was provided by the University of Hong Kong and the Ocean Park Conservation Foundation.

\section{LITERATURE CITED}

Alibert C, McCulloch MT (1997) Strontium/calcium ratios in modern Porites corals from the Great Barrier Reef as a proxy for sea surface temperature: calibration of the thermometer and monitoring of ENSO. Paleoceanography 12:345-363

Barnes DJ, Lough JM (1996) Coral skeletons: storage and recovery of environmental information. Glob Change Biol 2:569-582

Behairy AKA, Sheppard CRC, El Sayed MK (1992) A review of the geology of coral reefs in the Red Sea. Regional Seas Reports and Studies, no. 152, United Nations Environmental Programme, Nairobi

Buddemeier R, Smith S (1999) Coral adaptation and acclimatization: a most ingenious paradox. Am Zool 39:1-9

Carilli JE, Prouty NG, Hughen KA, Norris RD (2009) Centuryscale records of land-based activities recorded in Mesoamerican coral cores. Mar Pollut Bull 58:1835-1842

Chan ALK, Chan KK, Choi CLS, McCorry D, Lee MW, Ang PJ (2005) Field guide to hard corals of Hong Kong. Agricul- ture, Fisheries and Conservation Department, Government of Hong Kong SAR

Chiappone M, Sullivan KM (1991) A comparison of line transect versus linear percentage sampling for evaluating stony coral (Scleractinia and Milleporina) community similarity and area coverage on reefs of the central Bahamas. Coral Reefs 10:139-154

DeVantier LM, Done TJ (2007) Inferring past outbreaks of the crown-of-thorns seastar from scar patterns on coral heads In: Aronson RB (ed) Geological approaches to coral reef ecology, Vol 192. Springer, New York, p 85-125

DeVantier LM, McCorry D (2003) Corals and coral communities of Hong Kong: ecological values and status 20012002. In: Underwater survey of coastal waters of Hong Kong, AFD/SQ/19/01. Government of Hong Kong SAR

DeVantier LM, De'Ath G, Done TJ, Turak E (1998) Ecological assessment of a complex natural system: a case study from the Great Barrier Reef. Ecol Appl 8:480-496

DeVantier LM, Turak E, Al-Shaikh KA, De'Ath G (2000) Coral communities of the central-northern Saudi Arabian Red Sea. Fauna of Arabia 18:23-66

Done TJ (1982) Patterns in the distribution of coral communities across the central Great Barrier Reef. Coral Reefs 1: 95-107

Edinger EN Limmon GV, Jompa J, Widjatmoko W, Heikoop JM, Risk MJ (2000) Normal coral growth rates on dying reefs: Are coral growth rates good indicators of reef health? Mar Pollut Bull 40:404-425

Gagan, MK, Ayliffe LK, Beck JW, Cole JE, Druffel ERM, Dunbar RB, Schrag DP (2000), New views of tropical paleoclimates from corals. Quat Sci Rev 19:45-64

Glynn PW (1988) El Niño warming, coral mortality and reef framework destruction by echinoid bioerosion in the eastern Pacific. Galaxea 7:129-160

Grigg RW (1981) Coral reef development at high latitudes in Hawaii. In: Gomez E et al. (eds) Proc 4th Int Coral Reef Symp, Vol 1, Manila, p 687-693

Guan B, Fang G (2006) Winter counter-wind currents off the Southeastern China Coast: a review. J Oceanogr 62:1-24

Guinotte JM, Buddemeier RW, Kleypas JA (2003) Future coral reef habitat marginality: temporal and spatial effects of climate change in the Pacific basin. Coral Reefs 22: $551-558$

Harriott VJ (1999) Coral growth in subtropical eastern Australia. Coral Reefs 18:281-291

Harriott V, Banks S (2002) Latitudinal variation in coral communities in eastern Australia: a qualitative biophysical model of factors regulating coral reefs. Coral Reefs 21: 83-94

Hendy EJ, Lough JM, Gagan MK (2003) Historical mortality in massive Porites from the central Great Barrier Reef, Australia: Evidence for past environmental stress? Coral Reefs 22:207-215

Hodgson G, Yau EPM (1997) Physical and biological controls of coral communities in Hong Kong. In: Lessios HA, Mcintyre IG (eds) Proc 8th Int Coral Reef Symp, Vol. 1, Panama, p 459-464

Huang Z, Zong Y, Zhang W (2004) Coastal inundation due to sea level rise in the Pearl River Delta, China. Nat Hazards 33:247-264

> Hughen KA, Schrag DP, Jacobsen SB, Hantoro W (1999) El Niño during the last interglacial period recorded by a fossil coral from Indonesia. Geophys Res Lett 26:3129-3132

Hughen KA, Baillie MGL, Bard E, Beck JW and others (2004) Marine 04: marine radiocarbon age calibration, 0-26 cal kyr BP. Radiocarbon 46:1059-1086

Inoue M, Hata A, Suzuki A, Nohara M and others (2006) Distribution and temporal changes of lead in the surface sea- 
water in the western Pacific and adjacent seas derived from coral skeletons. Environ Pollut 144:1045-1052

Kawaguti S (1937) On the physiology of reef corals II. The effects of light on color and form of reef corals, Palao Trop Biol Stn Stud 1:199-208

Kleypas JA, Buddemeier RW, Archer D, Gattuso JP, Langdon C, Opdyke BN (1999a) Geochemical consequences of increased atmospheric carbon dioxide on coral reefs. Science 284:118:120

Kleypas J, McManus JW, Meñez LAB (1999b) Environmental limits to coral reef development: Where do we draw the line? Am Zool 39:146-159

Lee AHM, Liu JW (1998) Marine water quality in Hong Kong in 1997. Water Policy and Planning Group, Environmental Protection Department, Government of Hong Kong SAR

Leung KF, Morton B (1997) The impacts of dredging on the epibenthic molluscan community of the southeastern waters of Hong Kong: a comparison of the 1992 and 1995 trawl programmes. In: Morton B (ed) The marine flora and fauna of Hong Kong and Southern China, Vol 4. Hong Kong University Press, Hong Kong, p 401-436

Lough JM (2008) Coral calcification from skeletal records revisited. Mar Ecol Prog Ser 373:257-264

Lough JM (2010) Climate records from corals. In: Wiley interdisciplinary reviews: climate change, Vol 1. John Wiley \& Sons, Hoboken, NJ, p 318-331

Lough JM, Barnes DJ (1997) Several centuries of variation in skeletal extension, density and calcification in massive Porites colonies from the Great Barrier Reef: a proxy for seawater temperature and a background of variability against which to identify unnatural change. J Exp Mar Biol Ecol 211:29-67

> Lough JM, Barnes DJ (2000) Environmental controls on growth of the massive coral Porites. J Exp Mar Biol Ecol 245:225-243

Macintyre I (2003) A classic marginal coral environment: tropical coral patches off North Carolina, USA. Coral Reefs 22:474

Maragos JE, Cook CW Jr (1995) The 1991-1992 rapid ecological assessment of Palau's coral reefs. Coral Reefs 14:237-252

Marshall JF, McCulloch MT (2002) An assessment of the Sr/Ca ratio in shallow water hermatypic corals as a proxy for sea surface temperature. Geochim Cosmochim Acta 66:3263-3280

McCorry D (2002) Hong Kong scleractinian coral communities: status, threats and proposals for management. $\mathrm{PhD}$ thesis, University of Hong Kong

McCorry D, Blackmore G (1998) Tolo revisited: a resurvey of the corals and their metal burdens in Tolo harbour and channel twelve years and one million people later. In: Morton B (ed) The marine flora and fauna of Hong Kong and Southern China, Vol 5, Hong Kong University Press, Hong Kong, p 453-482

Morton B (1994) Hong Kong's coral communities: status, threats and management plans. Mar Pollut Bull 29:74-83

Morton B (1995) Hong Kong. In: Hotta K, Dutton IM (eds) Coastal management in the Asia-Pacific region: issues and approaches. International Marine Science and Technology Federation, Tokyo, p 197-208

Morton B (1996) Protecting Hong Kong's marine biodiversity: present proposals, future challenges. Environ Conserv 23:55-65

Morton B, Wu RSS (1975) The hydrology of the coastal waters of Hong Kong. Environ Res 10:319-347

Moyer R, Riegl B, Banks K, Dodge R (2003) Spatial patterns and ecology of benthic communities on a high-latitude south Florida (Broward County, USA) reef system. Coral Reefs 22:447-464

Nozawa Y, Tokeshi M, Nojima S (2008) Structure and dynamics of

Editorial responsibility: Charles Birkeland,

Honolulu, Hawaii, USA a high-latitude scleractinian coral community in Amakusa, southwestern Japan. Mar Ecol Prog Ser 358:151-160

Perry C (2003) Coral reefs in a high-latitude, siliciclastic barrier island setting: reef framework and sediment production at Inhaca Island, southern Mozambique. Coral Reefs 22:485-497

Reimer PJ, Ballie MGL, Bard E, Bayliss A and others (2004) IntCal04 terrestrial radiocarbon age calibration, 0-26 cal kyr BP. Radiocarbon 46:1029-1058

Scoffin TP, Tudhope AW, Brown BE, Chansang H, Cheeney RF (1992) Patterns and possible environmental controls of skeletogenesis of Porites lutea, south Thailand. Coral Reefs 11:1-11

Scott PJB (1990) Chronic pollution recorded in coral skeletons in Hong Kong. J Exp Mar Biol Ecol 139:51-64

Scott PJB (1991) The corals of Hong Kong. Hong Kong University Press, Hong Kong

Sheppard CRC, Sheppard A (1991) Corals and coral communities of Arabia. In: Fauna of Saudi Arabia, Vol 12. Natural History Museum, Basel, p 7-192

Sheppard CRC, Price A, Roberts C (1992) Marine ecology of the Arabian region: patterns and processes in extreme tropical environments. Academic Press, London

Southon J, Kashgarian M, Fontugne M, Metivier B, Yim WWS (2002) Marine reservoir corrections for the Indian Ocean and Southeast Asia. Radiocarbon 44:167-180

Tang D, Ni I (1996) Remote Sensing of Hong Kong water: spatial and temporal changes in sea surface temperature. Acta Oceanogr Taiwanica 35:173-186

Trott AW, Fung YC (1973) Marine pollution in Hong Kong. Mar Pollut Bull 4:13-15

Veron J (1980) Hermatypic Scleractinia of Hong Kong: an annotated list of species. In: Morton B, Tseng CK (eds) The marine flora and fauna of Hong Kong and southern China, Vol 1. Hong Kong University Press, Hong Kong, p 111-126

Veron J (1986) Corals of Australia and the Indo-Pacific. Angus and Robertson, North Ryde

Veron J (1995) Corals in space and time: the biogeography and evolution of the Scleractinia. University of New South Wales Press, Sydney

Wachenfeld D (1996) Standard operational procedure: videomonitoring of sessile benthic communities. Great Barrier Reef Marine Park Authority, Townsville

Wang W (1997) Some aspects of bay bar development in Hong Kong. PhD thesis, University of Hong Kong

Watts JCD (1971) A general review of the oceanography of the northern sector of the South China Sea. Hong Kong Fisheries Bulletin 2:41-50

Wicks L, Jonathan PA, Gardner PA, Cavy SK (2010) Spatial patterns and regional affinities of coral communities at the Kermadec Islands Marine Reserve, New Zealand - a marginal, high-latitude site. Mar Ecol Prog Ser 400:101-113

Wilkinson C, DeVantier LM, Talaue-McManus L, Lawrence D, Souter D (2005) South China Sea: global international water assessment. University of Kalmar

Yamano H, Hori K, Yamauchi M, Yamagawa O, Ohmura A (2001) Highest latitude coral reef at Iki Island, Japan. Coral Reefs 20:9-12

Yim WWS (1992) Future sea-level rise and coastal land reclamation for urbanization in Hong Kong. HK Met Soc Bull 2:3-11

Yim WWS, Nau PS, Rosen BR (1981) Permian corals in the Tolo Harbour formation, Ma Shi Chau, Hong Kong. J Paleontol 55:1298-1300

Yonge CM (1963) The biology of coral reefs. Adv Mar Biol 1:209-260

Zong Y, Huang Z, Switzer AD, Yim WWS (2009) An evolutionary model for the Holocene formation of the Pearl River Delta, China. Holocene 19:129-142

Submitted: March 16, 2010; Accepted: January 3, 2011

Proofs received from author(s): March 9, 2011 